National and Global Petroleum Assessment

\title{
Assessment of Tight-Gas Resources in Canyon Sandstones of the Val Verde Basin, Texas, 2016
}

\begin{abstract}
Using a geology-based assessment methodology, the U.S. Geological Survey assessed mean resources of 5 trillion cubic feet of gas and 187 million barrels of natural gas liquids in tight-gas assessment units in the Canyon sandstones of the Val Verde Basin, Texas.
\end{abstract}

\section{Introduction}

The U.S. Geological Survey (USGS) recently completed a geology-based assessment of technically recoverable tight-gas resources in the Canyon sandstones of the Val Verde Basin in southwest Texas (fig. 1). The Val Verde Basin is the foredeep to the late Paleozoic, north-verging OuachitaMarathon fold and thrust belt. "Canyon sandstones" is a collective term for several sandstone intervals deposited in deep-water environments in the developing foredeep during the Late Pennsylvanian (Missourian to Virgilian?) and Early Permian

(Wolfcampian) (Bebout and Garrett, 1989; Hamlin and others, 1995; Hamlin, 2009). Canyon sandstones include the lower Canyon sandstone, Sonora sandstone, and Ozona sandstone intervals (Hamlin and others, 1995; Hamlin, 2009). The lower
Canyon sandstone was not assessed in this study. The sandstones represent multiple phases of deposition in prograding slope channel and basin-floor submarine fan systems with varying directions of provenance. For example, the Ozona sandstones were sourced from the southwest, whereas the Sonora sandstones were sourced from the northeast (Hamlin, 2009). Maps of sandstone thicknesses (Hamlin and others, 1995; Hamlin, 2009) and production data guided the geologic definition of the assessment units in this study.

Four assessment units (AU) were defined and assessed in the Ozona and Sonora sandstones of the Val Verde Basin. The four assessment units are contained within the Permian Basin Paleozoic Composite Total Petroleum System (TPS). Given that approximately 15,000 wells have been drilled and tested in the Canyon sandstone, production "fairways" have come into focus through time that are defined by thicker sandstone intervals and thus denser drilling and production. These fairways were also used as a basis for $\mathrm{AU}$ definition. The production fairway in the Ozona sandstone is defined as the Ozona Sandstone Fairway Tight Gas AU (fig. 1), and the area surrounding the fairway is the Ozona Sandstone Peripheral Tight Gas AU. Likewise, the production fairway in the Sonora sandstone defined the Sonora Sandstone Fairway Tight Gas AU, and the surrounding area is the Sonora Sandstone Peripheral Tight Gas AU. The outlines of the peripheral AUs generally follow the Ozona and Sonora sandstone boundaries developed by Hamlin and others (1995). Assessment input data for the four AUs are summarized in table 1 .
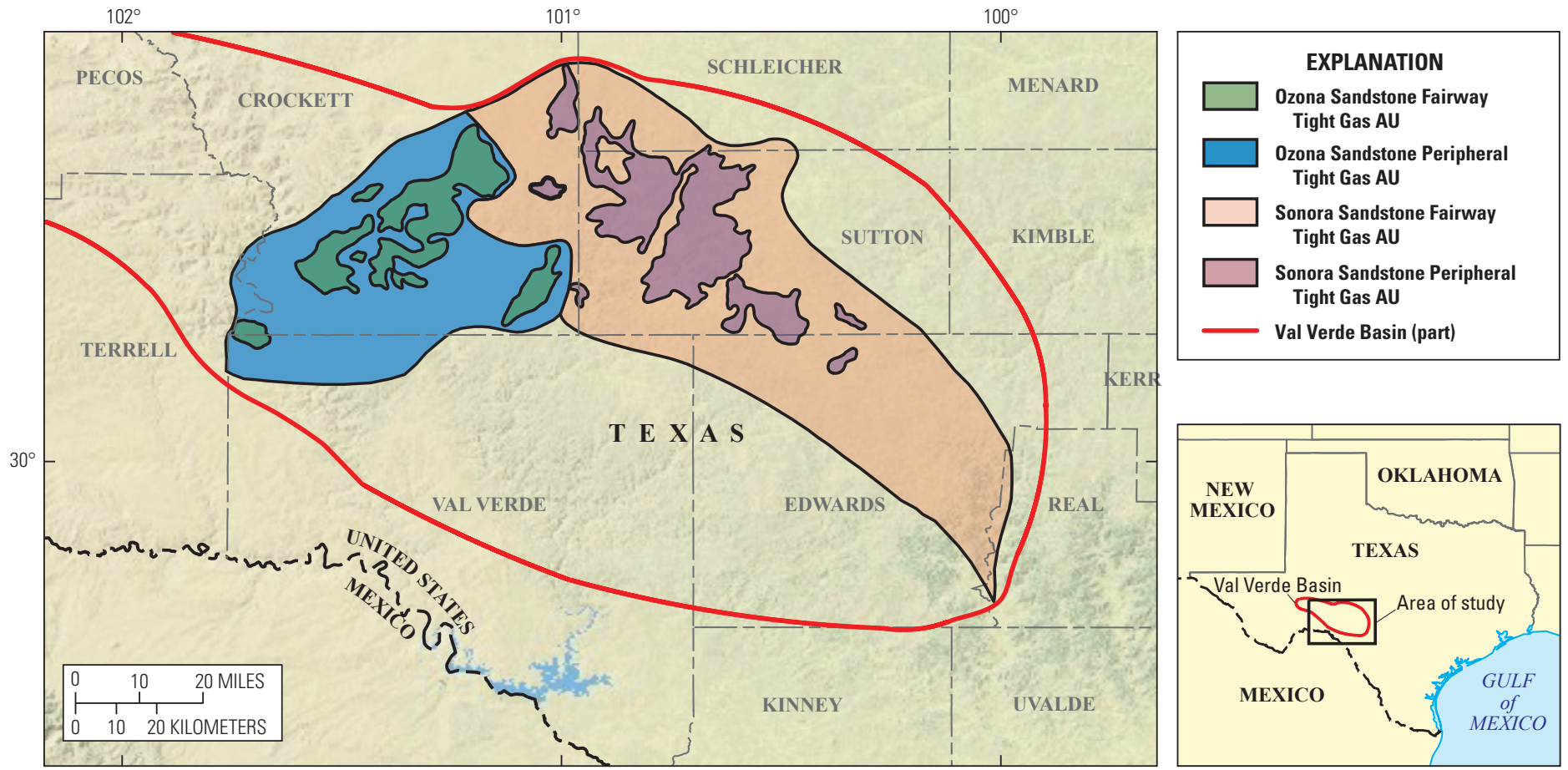

Source: National Park Service

Figure 1. Map of the Val Verde Basin, Texas. Assessment unit (AU) boundaries approximate facies maps of the various Canyon sandstones. 
